\title{
Health professions and health promotion: challenges in health and wellbeing among elite athletes
}

1 Joca Zurc

1 Alma Mater Europaea - ECM, Maribor, Slovenia and competition. These experience of gymnasts were confirmed by the opinions of their coaches.

Conclusion: the study provided important insights in the possibility of new quality approaches to the development of talented children in elite sports, in order to avoid possible risk factors and to ensure safety, health and wellbeing of every child.

Keywords: nursing, physiotherapy, health education, health promotion, elite sport, wellbeing of athletes

Article received: 30.07.2016.

Article accepted: 05.10.2016.

Corresponding author:

Asst. Prof. Joca Zorc, PhD KINS, PhD ethics

Oljčna pot 63A, 6000 Koper, Slovenia, EU

E-mail: joca.zurc@guest.arnes.si

Acknowledgements: The research was carried out at a PhD program at the Faculty of Arts, University of Ljubljana

\section{Introduction}

ing in elite female gymnastics has consequences on the gymnast's physical and mental health, it affects the abuse of painkillers, lack of education, sacrifices, and negative behavioural patterns in adulthood after finishing a sports career. The stated consequences are generated by verbal and physical violence of coaches, interests of the society over the interests of the athlete, and no professional nor personal support during training

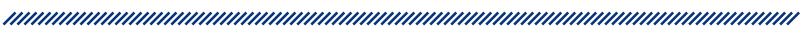

Health promotion is the fundamental strategy for controlling risk factors of unhealthy lifestyle and consequently improving health of the individual and the society. Many professional profiles promote health. Health science professions play a leading role in this process. 
Authors Edelman and Mandle ${ }^{1}$ emphasise that only health science professions can make a change in the lifestyle, and they particularly emphasise the importance of healthcare. Nurses play the key role in the improvement of the health of the population, as health education is an integral component of their professional role in their daily medical practice. In transitional research ${ }^{2}$, where we were determining opinions of graduated nurses - healthcare Master's programme studies on health promotion from the aspect of its key element; patient education in a clinical environment, we used empirical qualitative approach to determine that Master's programme students see the importance of education particularly in contribution to health of the patient, which is shown in the form of preparing the patient for an active role in treatment, taking care of their own health, restoring their health, and quality life with the disease. Research findings have shown the need for standardised education approaches in healthcare, which can be achieved with written and spoken preparation and education of healthcare workers according to various approaches and needs of the patients ${ }^{2}$. The key focus of education in healthcare is not only to deliver knowledge, but also changing health-related behaviour ${ }^{1}$. Education in healthcare also focuses on development of motivation, skill, and confidence of individuals required to trigger their behaviour, which will have an effect on improving their health ${ }^{3}$. Education in healthcare represents the learning process on health, which is shown in improved knowledge, development of skills, and changes in individual's behaviour, which is related to health and, as such, significantly promotes health with the approach that empowers individuals to take care of their own health ${ }^{4}$. Similar to the Brazilian research by Colomé and de Oliveira ${ }^{5}$, where, based on the sample of final year healthcare students, they determined that students see healthcare education as an interlaced concept of traditional and modern approach, our previous research ${ }^{2}$ with Master's healthcare students in Slovenia points out inclusion of the traditional medical model and modern holistic approach for strengthening health in education.

Elite sports with studies that prove the importance of healthcare professions for successful health promotion for elite athletes, are particularly marked in the field of healthcare professions for strengthening and protecting health. Sallen, Hemming and Richart ${ }^{6}$ have proven a positive effect of stress management training for the promotion of health and the prevention of illness among adolescent elite athletes. Most athletes in the study, who showed a medium or strong interest in attending stress management training, expressed high reactions to stress and reported positive self-efficacy. Edwards and Steyn ${ }^{7}$, in their empirical research, similarly find that psychological skills training programme affects psychological skills and psychological well-being of athletes. Triangulation approach, which included individual, group, and community interventions based on quantitative and qualitative methods, indicated improvements in psychological skills, psychological wellbeing and sporting performance.

Furthermore, the nutrition education programme for elite athletes, also contains statistically significant evidence on improvements of nutrition knowledge, dietary intake ${ }^{8}$, and in preventing eating disorders ${ }^{9}$. Aside from nutrition, education has an equal impact in oral health promotion programmes for elite athletes, to prevent high risk for caries, dental erosion and periodontal disease (i.e. gingivitis, periodontitis), which, according to athletes, have impact on their quality of life, confidence, training and performance, and may have long-term consequences ${ }^{10-12}$. Experimental intervention studies prove that health promotion programmes, oriented towards the Salutogenesis approach, enable elite athletes to acquire knowledge and skills for coping with overuse injuries ${ }^{13-15}$ and development of health management strategies ${ }^{16}$, which lead to suitable relaxation of stress and performance enhancement in elite sport training and competitions ${ }^{17}$. Development of promotion strategies and health protection in elite sport is particularly important with young, preadolescent athletes, when they start participating at the elite competitive level ${ }^{14,15}$. The International Olympic Committee Consensus Statement emphasises that training of the elite child athlete must ensure safe and healthy sports' career and promote future wellbeing of the child ${ }^{18}$.

\section{Purpose of the study}

The purpose of our empirical study was to gain insight in the role of health professions in order to promote and ensure health and wellbeing of elite athletes. We were interested in consequences of participation in elite sport on health and wellbeing among athletes on the example of women's artistic gymnastics from a critical reflection of active and retired elite gymnasts and their coaches. 


\section{Methods}

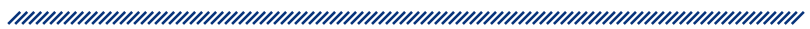

We designed a research based on the empirical qualitative interpretative phenomenological approach. It is a research approach, designed for studying life experience of individuals about their view of reality, from their description. Descriptions of experience of different individuals who have met with the studied phenomenon, contribute to its explanation ${ }^{19}$. We were interested in different perspectives and understandings of individuals with identical experiences, in order to comprehend everyday life of young elite athletes in women's artistic gymnastics.

\section{Procedure}

The research was performed as a part of an extensive doctoral dissertation research "Ethical Issues of top Achievements of Children', published by the author of this paper in 2015, at the University of Ljubljana ${ }^{20}$. Presented findings originate from second and third research phases of the mentioned research, where we used semi-structured in-depth retrospective interviews to study experience and views on the travelled path in elite sport by the most successful Slovene gymnasts who achieved top results before turning 18 years of age. Additional in-depth semi-structured interviews with coaches of interviewed gymnasts determined their perspective on creating top results, own experience and opinions on factors and ethical aspects, which occur on this path.

Interviews with gymnasts were performed from $18^{\text {th }}$ December 2012 to $18^{\text {th }}$ February 2013. Interviews with coaches of included competitors in gymnastics were done in the period from $22^{\text {nd }}$ December 2012 to $30^{\text {th }}$ January 2013. Time and place of individual interviews were arranged according to desires and the possibilities of research participants. Most interviews were done between 5 and $9 \mathrm{pm}$. Some interviews were also held in the mornings, during weekends, between 8 am and noon (i.e. between training sessions on Saturdays). The majority of the interviews were conducted on the premises of Zelena jama Gymnast Association and Gib Šiška Sports Association in Ljubljana, where the majority of national junior and senior team of female artistic gymnastics are training. Some interviews with retired top gymnasts had also been done at gymnasts' homes, at work, or in public places, such as cafeterias. Average duration of the interviews with active and retired gymnasts was 38 minutes and 55 seconds, the shortest one lasted 14 minutes, and the longest one was 2 hours and 12 minutes long. The average duration of the interviews with female sports gymnastics coaches was 54 minutes and 25 seconds.

The research is based on consideration of ethical research aspects, which include research in accordance with the Declaration of Helsinki-Tokyo. The process of collecting and protecting personal information was performed in accordance with the requirements of the Personal Data Protection Act ${ }^{21}$. Ethical aspects of the research were treated and confirmed by the Ethical Committee of the Department of Psychology at the Faculty of Arts of the University in Ljubljana in May 2010. All participants of the research signed a 'Statement on conscious consent of the participant for participation in the research on top achievements of children' before commencing the interview. In case of minors, their parents/legal representatives also signed the Statement. All submitted statements respect the right for privacy of interviewees, confidentiality, and anonymity of collected data. Names of individuals, locations, and institutions, time definitions and other demographic data, which might identify interviewees, were removed from the presented results.

\section{Sample}

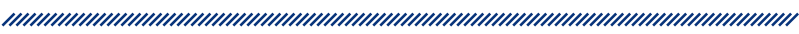

In-depth retrospective semi-structured interviews were carried out on a sample of 37 female gymnasts, of which 26 were active and 11 retired, and with 4 coaches of interviewed gymnasts. Research included top Slovenian active female gymnasts, current members of cadet, junior and senior national team of Slovenia, and national team members who have been members of Yugoslavian or Slovenian gymnast team at the end of the 1980s and at the beginning of 1990s. Beside membership in the team, participation at an international competition before the 
age of 18 was also the condition for being invited to participate in the research. The criterion for selecting interviewed coaches was that they are directly related to at least one of the interviewees in this research or were their current or past coaches. All interviewees were invited to participate in the research with a snowball sampling, which enables an access to dispersed, small, and specific populations, where criteria for selection are characteristics that are not common in general population or it is a delicate phenomenon of research ${ }^{22}$.

\section{Measures}

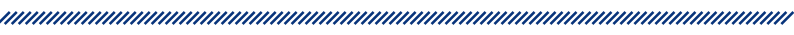

After the first pilot interview, where improvements in formulation of questions, order of questions, and framework of more sub-questions for each main topic were made, the final measurement instrument was used to gather empirical research data on the entire sample of 37 active and retired top gymnasts. After execution and analysis of the first pilot interview, the interview for female sports gymnastics coaches was designed on the basis of acquired findings. The paper presents results of the following semi-structure interview variables:

- view of active and retired gymnasts about the negative consequences of participating in elite sport during childhood,

- view of active and retired gymnast on the travelled path in sports gymnastics,

- view of coaches on the path of creating top achievement in sports gymnastics and which factors can affect it,

- view of gymnasts coaches about possible negative factors in the process of top achievements development by child.

Determining credibility, generalisation, consistency, and neutrality ${ }^{23}$, empirical research and measurement instrument - half-structured interviews were used at all levels of the research process and were based on using several different strategies, such as ${ }^{19}$ :

- triangulation: we gathered information for the studied phenomenon from various sources and perspectives from active, as well as retired gymnasts, and from their coaches, for a complete insight;
- collected interviews with 37 gymnasts and 4 coaches provide credibility and veracity to the findings;

- extended time for working on the research: the research ran from July 2009 to September 2015 and, in this period of continued work, provided deeper understanding of the phenomenon of creating top achievements during the childhood period,

- precise documenting of interview procedure with multiple (at least three-times) verification of transcript matching with the original sound recordings.

\section{Data analysis}

All interviews were recorded in MP3 digital form. Sound recordings of the interviews were consequently transcribed into written form - transcripts. In the phase of organising the collected data, each interview acquired its own code, which was created with three units (i.e. G-R-1/1-5, G-U-1/1-5) which means: G - gymnast, R - retired, $\mathrm{A}$ - active, $\mathrm{U}$ - coach of women's artistic gymnastics, 1/1-5 - consecutive interview number/sequence or size of the interview transcript.

Interview transcripts were analysed with the method of qualitative content analysis, in order to establish the main themes. We started the open coding process (providing meaning to individual segments of the text), this was followed by combining related notions (codes) to categories and forming judgements or explaining generalised relations between a specific category and its notions (axis coding), and between different categories (relational or selective coding) ${ }^{24}$. We concluded the qualitative analysis of empirical literature by forming a theoretical formulation on consequences of participation in elite sports on health and wellbeing among elite athletes in women's artistic gymnastics, from the aspect of reflection of active and retired top gymnasts and their coaches who have cooperated in the research. 


\section{Results}

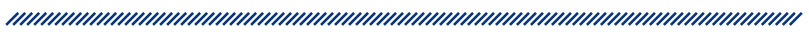

The results of interviews with active and retired gymnasts, presented in Table 1, show that the process of participating in top female gymnastics has consequences on the gymnast's physical and mental health, abuse of painkillers, lack of education, sacrifices, and negative behavioural patterns in adulthood after the sporting career has finished. Both groups experienced verbal and physical violence from their coaches, play interests of sporting policy, and have/had no professional and personal support during training and competition in the elite gymnastics. The differences among groups are only in the negative behavioural patterns in adulthood after the sporting career, and in the abuse of doping, which are indicated solely by retired gymnasts.

\section{Consequences on physical and mental health}

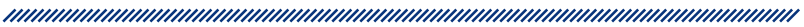

Gymnastics career is marked by many health issues throughout the process of training and competing, particularly by physical injuries and their long-term rehabilitation. Interviews with retired top gymnasts show that the athlete returned to the gymnastics hall as soon as this was possible. This was usually before the injury was fully healed, which often caused long rehabilitation, which left certain permanent consequences on gymnasts' health, which are still visible today, after ending the career.

"And then I injured my right elbow, and this means, I lost one year. I remember going to trainings with a cast, that we were doing strength exercises, but it is

Table 1. Perception of active and retired gymnasts about negative consequences of participating in elite sport during childhood

\begin{tabular}{|c|c|c|}
\hline Consequences & RETIRED GYMNASTS & ACTIVE GYMNASTS \\
\hline physical health & $\begin{array}{l}\text { sports injuries, long rehabilitation, } \\
\text { consequences after ending the career }\end{array}$ & $\begin{array}{l}\text { sports injuries, injury rehabilitation with insufficient } \\
\text { rest, great intensity in childhood }\end{array}$ \\
\hline mental health & $\begin{array}{c}\text { fear from elements, psychological } \\
\text { pressures, excessive perfectionism and } \\
\text { ambition, eating disorders }\end{array}$ & $\begin{array}{l}\text { psychological pressures, lack of motivation and } \\
\text { satisfaction, fear from competitions, personal crises } \\
\text { and the sensation of losing all the invested effort }\end{array}$ \\
\hline doping & abuse of painkillers & l \\
\hline $\begin{array}{l}\text { violence of a coach on a } \\
\text { gymnast }\end{array}$ & being ignored & $\begin{array}{c}\text { fear of the coach, mental pressures, punishments, } \\
\text { verbal violence, crying at training }\end{array}$ \\
\hline sacrifices & $\begin{array}{l}\text { disappointments, ambitions that did not } \\
\text { come true, hard work, forcing their body } \\
\text { to extremes, no profit }\end{array}$ & $\begin{array}{l}\text { gymnastics in the first place, all subjected to } \\
\text { trainings, no free time, routine, lack of rest, fatigue, } \\
\text { no friends, absence from home, parents adapting to } \\
\text { the career of their children, family without vacation }\end{array}$ \\
\hline sports policy & $\begin{array}{l}\text { cheating and wrongdoings, bribes, } \\
\text { injustice, no earnings, involuntary } \\
\text { replacement of participation, games of } \\
\text { financial interests, manipulations }\end{array}$ & $\begin{array}{l}\text { without the possibility of freely choosing their } \\
\text { free time, child does not understand special life } \\
\text { regime, role of the society in development of top } \\
\text { achievements }\end{array}$ \\
\hline no support & $\begin{array}{l}\text { passive role of parents, lack of } \\
\text { professional help }\end{array}$ & $\begin{array}{c}\text { passive role of parents, parents active in their fields, } \\
\text { parents are not experts in gymnastics }\end{array}$ \\
\hline effects on education & lack of success in school & $\begin{array}{l}\text { selecting educational institution subjugated to } \\
\text { training conditions, school schedule adjustment } \\
\text { to the regime of the gym club, lack of time for } \\
\text { education }\end{array}$ \\
\hline $\begin{array}{l}\text { negative behavioural } \\
\text { patterns in adulthood after } \\
\text { sports career }\end{array}$ & $\begin{array}{l}\text { grudges, compulsive behaviour, pushing } \\
\text { limits, excessive concern for others, } \\
\text { extreme perfectionism }\end{array}$ & l \\
\hline
\end{tabular}


not the same any more. Afterwards, the elbow was... I still have it, I can almost extend it now, but I could not extend or close the elbow at the time... On bars, those first images after the injury, one arm is bent, and the other is extended. Also on the balance beam, when you extended your elbows, l extended them the same, but one arm was not extended... Now my elbow hurts a bit during bad weather" (G-R-8/8-9).

Occurrence of physical injuries is equally expressed with active athletes. They list loss of opportunity of participating in specific competitions, interruption of training and sports career as the consequence of the injury. The injury might occur at an early age, which is a consequence of intensive training in youth and represents a demanding return to competitions.

"... I had many problems with injuries, really, I missed the first youth European championship, I could not even run for the position due to the injury. Then I qualified for the Olympics for the youth..., but I had to miss it because of the injury" (G-A-13/1).

Retired and active gymnasts pointed out physical pressure, fear from elements or changes in sensations of already learned elements, excessive perfectionism and ambition, problems with maintaining body weight, and suitable nutrition.

"At some point, I had problems with nutrition I think or how you call it... I think that the reason is that we did not get enough information about nutrition; I think no one paid any attention to our nutrition... There were more in a similar situation like I was in that period... But, if we had staff to help us about this, or a psychologist, as there were many girls who were afraid of specific elements, which were actually easy, but they had a click in the head because they could not do it. We would definitely need a psychologist, a nutrition expert... We were in a period when these things were not available" (G-R-5/6-7).

Active gymnasts also pointed out physical burden they experience as leaders of a group, lack of motivation and satisfaction in training, fear from competitions, personal crises, and the feeling of losing all invested effort, which is not being returned through the desired sports achievements.

"... I was at my best at the time, I was really fit, but I couldn't take it mentally. I had a small crisis in gymnastics back then. I didn't feel like competing, I felt that I invested a lot and all that, and I failed at what counted back then. I experienced it as a big personal failure" (G-A-13/1).

\section{Violence on gymnasts and doping}

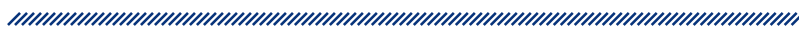

Violence at training and competitions has been shown through doping in retired gymnasts, which is primarily represented by the abuse of pharmaceuticals to control pain when performing with an injury.

"Yes, I took many pills back then just to try, I mean, to have a chance, but in the end not even the pills worked... Nalgesin at first, or something similar, didn't'work at all since the beginning, hmm, then I found some that worked if I took two, but... Yes, Naklofen, but I knew that I was going to destroy myself if I continued like this" (G-R-9/4).

With active gymnasts, violence is shown in fear of the coach, mental pressures in training, and as abuse of gymnasts with the intention of achieving top results in the shortest possible period. Violence can include penalties and verbal abuse by the coach and is shown by children crying during training. Gymnasts fear coaches for their strictness, lack of control of their own emotions, changes in work manners, or due to family relations.

"My coach is my father. I was afraid at the beginning... That he might, hmm, that he will be more, hmm, I do not know, that he will be more strict with me or something like that, that he will dare more and try more" (G-A-21/1).

\section{Disappointments, sacrifices, and sports politics}

Competition, as a central category in a career of every elite athlete, also brings some negative aspects of professional gymnast path, such as disappointments, unrealised ambitions, and missed opportunities of performing at competitions, which retired gymnasts still want to achieve in present time, like referees in example.

"So, maybe some things I didn't achieve as a competitor, like going to the world championships, I achieved as a referee. I'm still trying to realise some goals I didn't achieve back then" (G-R-11/1).

Games of political interests of club and sports associations, frauds (i.e. bribes, 'judges' kitchen') and wrong- 
doings (i.e. replacements in competitions, rivalry within a team and between clubs).

"I experienced it personally... Before the 1980 Olympics in Moscow... I was in a room with another referee when one Russian girl entered the room with a vase. And she put that vase on the table with some candy, and she said: "If our competitor, this and this name, performs this element, you give her 9.9, if she doesn't do it, you give her what you feel like", and she left that vase there... I think it was a sort of a bribe, I don't know what was in the vase... I was a competitor back then; I was 16 years old when I saw it. We weren't paying attention to these things back then, but I remembered when I heard it" (G-R-2/4).

It was characteristic for the Yugoslavian gymnastics system that elite gymnasts did not receive any regular income for their work and results, which consequently lead to ending their career.

"The situation was that gymnastics did not actually provide an income. Especially when I was training, I had no income and I couldn't continue for long. And that is why I decided to quit when I was 20 years old" (G-R-6/1).

Retired gymnasts also remember very well and are critical about various financial interests, manipulations, and feelings of being abused, which they were receiving during their competitive period to create success for their sports association. They state that the system was well-thought, that they skilfully moved them from children's gymnastics play into elite sport, which they were neither aware of nor they wanted it. Most negative feelings of abuse have remained in financial interests of sports associations, even more than three decades after completed careers.

"I saw only money here, there were some finances in play, and that is why they strive to make you better, and even better. I also remembered that everything is fine while you are good... But exactly this, because it was expressed... That it has to be done, that we go, that we win, because the association receives this amount and OK. Looking at it now, where are you?" (G-R-3/16).

Gymnastics is a central activity for the interviewed active gymnasts. It is in the first place in their lives, and they prioritise it before all other obligations. Their daily schedule is a routine, which is performed in the same rhythm from the beginning of training of elite sport in lower grades of elementary school, to graduat- ing in higher education and training gymnastics. They experience lack of spare time for themselves, time for school, time for friends, and the possibility of sufficient rest as the most difficult, especially during higher load of school obligations. Specific lifestyle of a gymnast is marked by sacrifices in selecting leisure activities of their own desire, absence from home, parents and entire families adapting to sports career of the child, and lack of understanding of this special lifestyle regime in this period of childhood.

"Not that you don't like childhood, but you can't, when you're eight or nine years old, you want to go and play outside with friends, play ball, I don't know, at the playground, whatever, this is not possible, you go to train and then you're here in the gym and you train. This is the only thing I miss and that parents had to adjust to me so much. This is also quite unfair to them... When I wanted to stay home for the holidays, and they wanted to go somewhere, we had small arguments about it" (G-A-26/7).

\section{Lack of support and education}

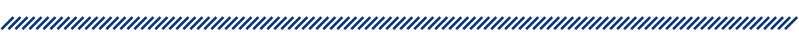

Negative memories that retired gymnasts want to change include lack of professional assistance and parental support, which they needed during their sports career and when they were ending it, but they did not receive it.

"Yes, maybe with those acrobatics backwards, to change... That fear... I didn't have a psychologist or an expert" (G-R-10/11).

"But you know, I had no support at home. We ate porridge, stews and such, because we had no money for meat or fruit. For Christmas, mum brought two bananas and two oranges... We ate bread and what we had; parents could not take care of nutrition" (G-R-2/24).

Interviews with active gymnasts showed that some parents are not including themselves in activities of their children in elite sports. They leave the decisions to the child and monitor their sports path from a side line, without putting aside their needs, career development and leisure activities.

"I return from training around seven... And I study or I do my homework if I have something left, then I eat 
dinner... It takes some time for dinner to be ready because my mother is training dogs and also arrives at half past six and not a lot of food is made" (G-A-18/1).

Regular education along gymnastics is characteristic for active elite gymnasts, where they subdue the selection of the institution to training conditions of gymnastics. It is no surprise that schools adapt to the regime of a gymnast club.

"In high school, I had the best... gymnastics was part of it so I joined trainings during sports class, hmm, all the time, in the morning, in the afternoon. I devoted everything in high school to gymnastics. At first, I thought of going to another school, but then I selected this high school, also because I will be able to train" (G-A-13/2).

Although schools paid attention to top elite sports, active and retired gymnasts point out the lack of time for studying due to gymnastics, which is shown in the sensation of missing out on general education, poor results, and in the demanding transition to tertiary, higher education.

\section{Negative behavioural patterns in adulthood}

Retired gymnasts stated that work methods bothered them during their career (i.e. insisting on intensity, hard work), which is also shown in their current self-destructive behavioural patterns (i.e. pushing beyond limits, exaggerated concern for others, excessive perfectionism).

\footnotetext{
"Today I am performing one of an alternative physical treatment here... And you need to be very precise; it matters if you draw dots, lines this way or a bit differently. And you can repeat. And I will also be here for a half an hour, I mean, if it is necessary. If I'm not sure, positive, I will repeat it ten times... I can see myself, again, again, and again..." (G-R-3/17).
}

The obtained findings of gymnasts were confirmed through the views of their coaches. For achieving top results, it is important to overcome the difficulties that occur, which mostly refer to the child's developmental changes, mental and physical health problems, and difficulties in the acquisition of knowledge (Figure 1). Ac- cording to opinions of coaches, the stated problems are most often caused due to verbal and physical violence from the coach, the absence of parents, and because of the interests of the society over the interests of an individual. Many other undefined and unknown factors also affect occurrence of problems for athletes.

According to opinions of interviewed gymnastics coaches, most important body problems include pain in the locomotor system, such as various inflammations of tendons and muscle pain and injuries due to lack of control or even systematic errors in training.

"Injury can be a consequence of improper system error during training... When I came [note - to this club], she was completely broken. She didn't have a single bone in the body that was in one piece... When I came... [note gymnast's name] shoulder has been operated, ... [note - gymnast's name] shoulder has been operated, [note gymnast's name] had a shoulder injury, she can't train on bars, one girl here from the club, ... [note - gymnast's name], operated shoulder. This is from the same coach, same error, this means system error of training. This is not coincidental; it happened to everyone in the gym..., same injury of four different gymnasts" (G-U-4/2).

Interviewed coaches also mentioned limitations in physical capabilities, which are related to body constitution and innate motor predispositions, and body changes as the consequences of growth and development, which largely relate to adolescence period in which significant body changes occur, such as increase in body fat, shape and composition, and consequently related change in centre of gravity (Figure 1). Doping is occurring in the form of system-managed process in gymnastic training, while it has no relevant effects in competitions due to characteristics of gymnastic elements.

"...There was a programme where all the girls were filled with hormones and then many things happened, mostly they got more hair" (G-U-1/2).

Mental problems on the path to creating an elite achievement in female sports gymnastics are shown through various anxieties, such as fear from performing and fear from meeting the expectation, and many psychosomatic problems where mental problems are shown in the form of body pain.

"Fear is one of the crucial factors, which occurred in the past twenty years, girls have great fears, which did not happen in Yugoslavia and in the Soviet Union. We don't know why these fears exist. And it's simply like that; if a girl is super capable, super light, coor- 
dinated, and she has fear from learning difficult elements, the case is closed. And sadly, there are more and more of such children. This means, we only have 15 girls in younger categories in Slovenia with similar capabilities, and only three of them are not afraid and those three will succeed" (G-U-3/2).

According to the interviewed coaches and teachers, causes of these problems are mental pressures and great expectations from parents, coaches, wider society or children themselves.

"But I can tell that we have problems with parents on many occasions. It happens that parents expect that their children will always be first if they include them in an elite sport. Only one can be first in a competition, right... Hmm, we have no problems with the girls where we do quality sports, not with girls and not with parents; everything is working really well there. But everything that goes into elite sports is too ambitious in many cases. You must be ambitious, but it would be much better if the child would be ambitious and not the parent" (G-U-2/2-3).

The third segment of problems that young talented female gymnasts can face on their way towards great achievement, by the opinion of interviewed coaches, are issues in acquiring knowledge. These problems are shown as poor training efficiency and obstacles in child

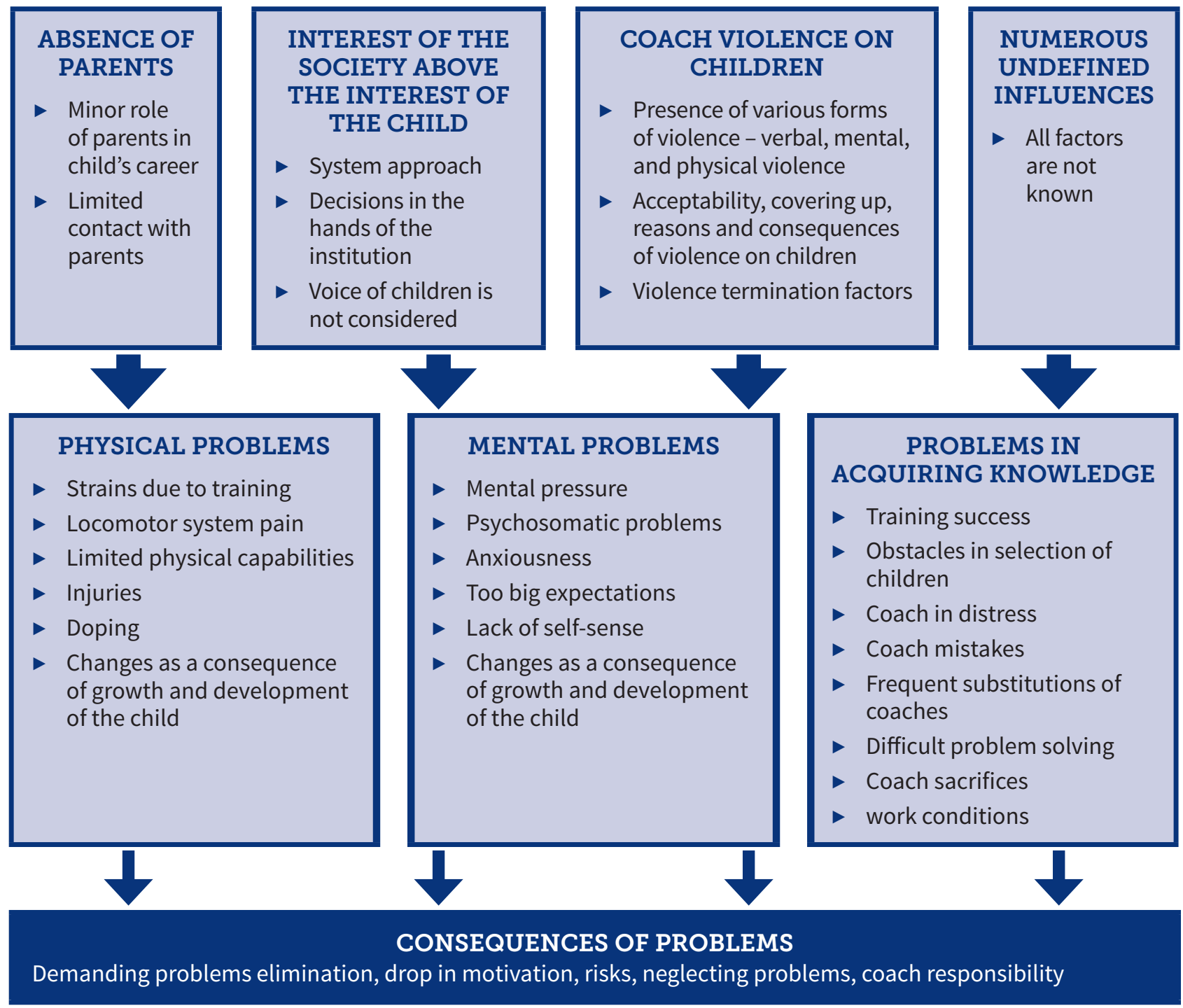

Figure 1. View of gymnastics coaches on possible unwanted phenomena in the process of creating elite achievements of a child 
selection, where complicated administrative procedures disable most talented children to get into sports clubs. Coaches say that, in the past, doors into public and educational institutions, such as kindergartens and elementary schools, were widely open for selection of talented children. This is no longer possible; parents are the only initiative for bringing the child into the gym.

Coaches' violence against children, absence of parents, predominant interest of the society over the interest of the child, and many other undefined factors importantly affect the occurrence of physical problems, mental problems, and problems in acquiring new knowledge. Between various forms of coaches' violence against an athlete, verbal abuse is predominant and is shown in the form of yelling, insulting, cynical comments, and criticizing children. It is followed by mental abuse, which focuses on self-image of the child and the feeling of value, and physical abuse, which is most often shown in the form of punching them in the arms and legs. The analysis also showed that violence in elite female sports gymnastics is covered up on one side and accepted or even denied on the other. Termination of violence usually occurs only when the child leaves the system. This can be represented as ending the career or changing the coach.

Interests of the society that are above the interests of a child show the influence of institutions that decide on the sports path of a child, where they do not consider the interests of the child. The child does not have personal freedom in direction or in making decisions on ending the career. With normal eight working hours a day, the child becomes an employee in a controlled institution of the country. This produces many wrongdoings and dishonesties, which they face on their path.

"... As a factory worker, but she received her father's salary as a faculty teacher twelve times... This means that the entire family, 17 people, lived off it. There was no chance that she says I can't, I don't want to, I won't, and that she goes home. Because those people would get her themselves and bring her back" (G-U-1/2).

Interviewed coaches warned that every activity, performed above the level of moderate participation, may harm the child. They believe that it is crucial to strive to progress in the process of developing the child's talent, while they are able and injuries do not occur. That is why the responsibility of the coach is crucial for creating top achievements.

"Look, I'll say it like this, we are not going to play nice. Each thing in which a person gets involved more than it is normal, can harm the child. It is not good if someone plays a piano for six hours a day, if they sit at the computer the whole day, it is the same if you are in here for six hours" (G-U-1/7).

\section{Discussion}

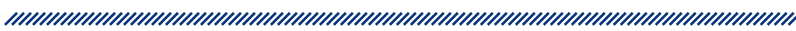

The acquired results of qualitative research provide an insight into understanding the role of health professions in health promotion and wellbeing among elite athletes. Our study showed that the best athletes face numerous problems and consequences on their physical and mental health on their way of creating a top achievement, as well as after ending their career. Results show that the process of participating in elite female artistic gymnastics brings abuse of painkillers, lack of education, sacrifices, and negative behavioural patterns in adulthood. The stated consequences are generated by verbal and physical abuse of coaches, by interests of the society being more important as the interests of an athlete, and by no professional and personal support during training and competition. The latter represents possibilities for inclusion of healthcare professions in prevention and development of health promotion in elite sports for children.

We have determined that most common injuries in Slovene elite gymnastics are those that may result in interruption or even conclusion of the career. Ivković et al. ${ }^{25}$ see the reason for injuries in female sports in the overuse factor, which is a result of imbalance between the intensity of training and insufficient recovery as the consequence of inadequate restoration mechanisms in tissues. Farstad's research ${ }^{26}$ also confirms this. The research states that sports injuries, which happen due to overuse, may occur in every sport, but girls in gymnastics and in figure skating are particularly vulnerable, as motor skills have become so demanding that only petite and fragile bodies of juvenile girls can perform them. In the field of controlling overuse injuries in elite sports, health promotion programmes ${ }^{13,14}$ have an important role, as well as active and devoted cooperation between key stakeholders, such as government health agencies, sports bodies, sports administrators, clinicians, researchers, sports' clubs, coaches and the participants themselves ${ }^{15}$. 
Farstad ${ }^{26}$ also pointed out other consequences of children participating in elite female sports gymnastics, which match the findings of our research; occurrence of eating disorders, lack of time for resting, physical, mental, and sexual violence, poor results in school, absence from parents and delay in social development. Prevention and health promotion programmes are important for preventing the latter as they can improve nutrition habits $^{8}$, prevent the occurrence of eating disorders ${ }^{9}$ and improve balance of effort and relaxation in elite sports ${ }^{17}$.

Our research uncovered practices where gymnasts usually continue training and competing when injuries or other health issues occur, reaching the very limits of the body or excruciating pain, which stops them. For the latter to be possible, abuse of painkillers occurs. Statements of retired interviewed gymnasts show that such practices were mostly performed on the basis of coach's decision, but with simultaneous consent of athletes. Use of any drugs with the purpose of increasing competitive efficiency is classified as doping in sports by the World Anti-Doping $\mathrm{Code}^{27}$. This is particularly important in the so-called risk sports for doping abuse. Bochaver and Kasatkin ${ }^{28}$ state that, among 93 analysed sports next to cycling, athletics and weight lifting, gymnastics is categorised among the risk sports, where increased level of tolerance of young athletes towards taking sports results improving substances is determined. Still, the 'fight against doping' has the highest priority in the International Sport Federations, followed by 'care for the health of an elite athlete' and 'effort for safe sport' ${ }^{29}$.

Our research showed that occurrence of problems of gymnasts might be a consequence of verbal and physical violence of the coach towards the athlete during training or competition in gymnastics. This opens the issue of ethical relationship towards treatment of children in elite sports and protection of their rights and wellbeing in accordance with the Convention of the Rights of the Child ${ }^{30}$. The acquired findings go in line with the findings of the research by Stirling and Kerr ${ }^{31,32}$ and Collins ${ }^{33}$, who also showed the occurrence of verbal and physical violence on athletes, body weight control, and isolation of elite athletes. The determined system approach towards development of talented children in female sports gymnastics, with the purpose of achieving implementation and superiority of one country in relation to other countries, exposes interference of the country with the life of individuals. This is why understanding of established practices of creating top achievements of children should be contributed to social and national interests.
Active and retired gymnasts, involved in our research, further pointed out the passive role of parents in their sports career, which is the consequence of absence of parents due to preoccupation with their own activities or lack of knowledge on gymnastics. Coaches of interviewed gymnasts confirmed that cooperation with parents is a very important factor in creating a top achievement. McArdle in Duda ${ }^{34}$ revealed a connection between parental support and self-image of athletes. Parents' critique is the strongest indicator of worry and doubts about actions of young athletes, while support and positive expectations of parents forecast positive emotions of own value of a young elite athlete. Coaches of interviewed gymnasts point out the importance of pedagogic approach, from the aspect of encouraging child's development and talent, direction and control, suitable qualification of the coach, coming over obstacles and inclusion of a multidisciplinary team of various experts, such as gymnastics coach, choreographer, psychologist, educator, diabetologist, physiotherapist, and a doctor.

Based on the acquired findings, we can conclude that the need for presence of healthcare professions in elite sports, as strategic stakeholders of promotion and protection of health of elite young female gymnasts, exists. The need for contractors that would provide additional knowledge from this field, is shown, while the employer should also provide additional courses, along with motivation of a healthcare worker ${ }^{2}$. Special attention must be paid to the development of didactic approaches and strategies of promoting health programmes for elite athletes.

\section{Study limitations and opportunities for the future research}

The research is based on a qualitative sample of elite athletes, all coming from a single selected sport, which is why the acquired results primarily apply to members of national teams in female sports gymnastics in the studied period. Future research should include views on health promotion and the role of health professions in other sports. The issue of appearance, implementation forms, and success rate of health promotion programmes in various elite sports also remain open and should be studied with a cross-sectional study. 
The size of the studied sample of 37 elite athletes in female sports gymnastics definitely provides a priceless insight into the world of elite female sports gymnastics, but at the same time, it also presents a certain limitation of the research. This resulted in a longer period of collecting data, and extensive, complete, and timedemanding production of transcripts and qualitative data analysis. Selection of the interviewees sample was performed with the snowball method, which enabled us a unique access and inclusion into a closed social community of elite gymnasts and their coaches. Ritchie and Lewis ${ }^{22}$ point out that sampling with the snowball method can also have specific limitations from the aspect of sample dispersion. This is a consequence of the approach where new sample members are suggested by the existing ones, where the latter usually suggest friends or acquaintances who have similar experience and characteristics as themselves. The used sampling method also turned out to be time consuming for our research as it is based on a successive approach for data collection, which disables larger control of dynamics and balance of sampling.

In this research, we focused on the view of athletes and their coaches. In the so-called sports triad, the third observation angle - the one of parents of elite athletes - is also indispensable and equal. Triangulation with combination of quantitative and qualitative methodological approaches can provide an insight to understanding of the studied phenomenon from three key stakeholders in creating top achievement of a child.

\section{Conclusions}

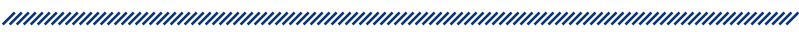

The study findings provided important insights on the possibilities of new quality strategies and approaches for developing talented children in elite sports in order to avoid possible risk factors and to ensure safety, health and wellbeing, and holistic development of every child. In order to achieve top sports results, all elite athletes must risk and protect their health at the same time. On the path of creating a top achievement, they are facing the dilemma between preserving optimum health and taking health risks by pushing their physical limits. Trilemma appears during adolescence, which is marked by developmental changes that are characteristic to the period of growing up ${ }^{35}$. This poses a challenge and opportunities for developing health protection and promotion strategies in elite sports by healthcare professions. In the following studies, we need to focus on developing health promotion programmes in elite sports for encouraging, protecting, and strengthening health of pre-adolescent elite children athletes.

\section{References}

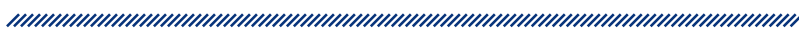

1. Edelman CL, Mandle CL. Health promotion throughout the life span, 7th ed. Missouri: Mosby Elsevier; 2010.

2. Zurc J. Edukacija v zdravstvu: pogled magistrskih študentov zdravstvene nege. In: Skela-Savič B, Hvalič Touzery S, eds. Zdravstvene stroke in njihov odziv na zdravstvene potrebe družbe: na dokazih podprto in usklajeno delovanje: Zbornik predavanj z recenzijo 8. mednarodne znanstvene konference, 11.-12. junij 2015, Bled, Slovenija [Health care professions and their response to the health care needs of society: an evidence based and coordinated action: Proceedings of lectures with peer review of the 8th international scientific conference, $11^{\text {th }}-12^{\text {th }}$ June 2015 , Bled, Slovenia]. Jesenice: Faculty of Health Care; 2015:188-195.

3. Wills J, ed. Promoting Health. Oxford: Blackwell Publishing Ltd.; 2007.

4. Maville JA, Huerta CG. Health promotion in nursing, 2nd ed. Clifton Park, New York: Delmar; 2008.

5. Colomé JS, de Oliveira DL. Health education from the perspective of nursing undergraduate students. Revista Gaucha de Enfermagem. 2008;29(3):347-353.

6. Sallen J, Hemming K, Richartz A. Promotion of health and prevention of illness among adolescent elite athletes: Attractiveness of pedagogical-psychological training against daily stress. Sportwissenschaft. 2015;45(2):95-101.

7. Edwards DJ, Steyn BJM. Sport psychological skills training and psychological well-being. South African Journal for Research in Sport, Physical Education and Recreation. 2008;30(1):15-28.

8. Martinelli L. The implementation and evaluation of a nutrition education programme for university elite athletes. Progress in Nutrition. 2013;15(2):71-80.

9. Martinsen M, Bahr R, BØrresen R, Holme I, Pensgaard AM, Sundgot-Borgen J. Preventing eating disorders among young elite athletes: A randomized controlled trial. Medicine and Science in Sports and Exercise. 2014;46(3):435-447.

10. Needleman I, Ashley P, Fine P, Haddad F, Loosemore M, Medici AD, Donos N, Newton T, Someren KV, Moazzez R, et al. Oral health and elite sport performance. British Journal of Sports Medicine. 2015;49(1):3-6. 
11. Needleman I, Ashley P, Petrie A, Fortune F, Turner W, Jones J, Niggli J, Engebretsen L, Budgett R, Donos N, et al. Oral health and impact on performance of athletes participating in the London 2012 Olympic Games: A cross-sectional study. British Journal of Sports Medicine. 2013;47(16):1054-1058.

12. Bryant S, McLaughlin K, Morgaine K, Drummond B. Elite athletes and oral health. International Journal of Sports Medicine. 2011;32(9):720-724.

13. Mayer J, Thiel A. Health in elite sports from a salutogenetic perspective: Athletes' sense of coherence. PLOS ONE. 2014;9(7):e102030. Available from: http://journals.plos. org/plosone/article?id=10.1371/journal.pone.0102030 (accessed 11 Jun 2016).

14. Timpka T, Risto O, Björmsjö M. Boys soccer league injuries: A community-based study of time-loss from sports participation and long-term sequelae. European Journal of Public Health. 2008;18(1):19-24.

15. Gabbe BJ, Finch CF, Cameron PA. Priorities for reducing the burden of injuries in sport: The example of Australian football. Journal of Science and Medicine in Sport. 2007;10(5):273-276.

16. Thiel A, Diehl K, Giel KE, Schnell A, Schubring AM, Mayer J, Zipfel S, Schneider S. German young Olympic athletes' lifestyle and health management study (GOAL study): design of a mixed-method study. BMC Public Health. 2011;11:410. Available from: http://www.biomedcentral. com/1471-2458/11/410 (accessed 14 Apr 2014).

17. Klockare E, Gustafsson H, Davis P, Lundqvist C. Track and field athletes' experiences and perceived effects of flotation REST: An interpretative phenomenological analysis. International Journal of Sport Psychology. 2015;46(5):409-428.

18. Mountjoy M. IOC consensus statement on training the elite child athlete. Science and Sports. 2008;23(2):98-101.

19. Creswell JW. Research Design: Qualitative, Quantitative, and Mixed Methods Approaches. Thousand Oaks, California: Sage Publications, Inc.; 2014.

20. Zurc J. Etična vprašanja vrhunskih dosežkov otrok: [doctoral dissertation]. Ljubljana: University of Ljubljana, Faculty of Arts; 2015.

21. Zakon o varstvu osebnih podatkov (uradno prečiščeno besedilo). Uradni list Republike Slovenije. 2007;94/2007. Available from: http://www.uradni-list.si/1/objava.jsp?urlid= 200794\&stevilka=4690 (accessed 19 Aug 2015).

22. Ritchie J, Lewis J. Qualitative Research Practice: A Guide for Social Science Students and Researchers. London, United Kingdom: Sage Publications, Ltd.; 2006.

23. Lincoln YS, Guba EG. Naturalistic Inquiry. Newbury Park, CA: Sage Publications; 1985.

24. Adam F, Hlebec V, Kavčič M, Lamut U, Mrzel M, Podmenik D, Poplas Susič T, Rotar Pavlič D, Švab I. Kvalitativno raziskovanje $v$ interdisciplinarni perspektivi. Ljubljana: Inštitut za razvojne in strateške analize; 2012.

25. Ivković A, Franić M, Bojanić I, Pećina M. Overuse injuries in female athletes. Croatian Medical Journal. 2007;48(6):767-778.
26. Farstad S. Protecting Children's Rights in Sport: The Use of Minimum Age: [master thesis]. Fribourg, Switzerland: University of Fribourg; 2006.

27. World Anti-Doping Agency. World Anti-Doping Code. Montreal, Quebec, Canada: World Anti-Doping Agency; 2009.

28. Bochaver A, Kasatkin VN. The characteristics of attitudes towards performance-enhancing drugs in sport in Russia. Psychology and Health. 2010;25(1):137-376.

29. Mountjoy M, Junge A. The role of International Sport Federations in the protection of the athlete's health and promotion of sport for health of the general population. British Journal of Sports Medicine. 2013;47(16):10231027.

30. United Nations. Convention on the Rights of the Child: General Assembly Resolution 44/25. New York: United Nations General Assembly; 1989. Available from: http:// www.ohchr.org/en/professionalinterest/pages/crc.aspx (accessed 9 Sep 2015).

31. Stirling AE, Kerr GA. Defining and categorizing emotional abuse in sport. European Journal of Sport Science. 2008;8(4):173-181.

32. Stirling AE, Kerr GA. Emotional abuse in Canadian sport. In: Brackenridge CH, Kay T, Rhind D, eds. Sport, Children's Rights and Violence Prevention. London: A Sourcebook on Global Issues and Local Programmes, Brunel University Press, Brunel University; 2012:106-111.

33. Collins $\mathrm{T}$. The impact of child protection on high-performance British gymnastics. In: Brackenridge $\mathrm{CH}$, Kay T, Rhind D, eds. Sport, Children's Rights and Violence Prevention: A Sourcebook on Global Issues and Local Programmes. London: Brunel University Press, Brunel University; 2012:94-98.

34. McArdle S, Duda JL. Exploring the etiology of perfectionism and perceptions of self-worth in young athletes. Social Development. 2008;17(4):980-997.

35. Diehl K, Thiel A, Zipfel S, Mayer J, Schneider S. Substance use among elite adolescent athletes: Findings from the GOAL Study. Scandinavian Journal of Medicine and Science in Sports. 2014;24(1):250-258.

\section{Acknowledgements}

Author of the paper sincerely thanks to all participating top athletes in female sports gymnastics and their coaches from the Zelena jama Gymnast Association and Gib Šiška Sports Association in Ljubljana for valuable cooperation in the research, which forms the foundation for the findings of this research. 


\section{ZDRAVSTVENE PROFESIJE I PROMOCIJA ZDRAVLJA: IZAZOVI ZA ZDRAVLJE I DOBROBIT VRHUNSKIH SPORTAŠA}

1 Joca Zurc

1 Alma Mater Europaea - ECM, Maribor, Slovenija

\section{Sažetak}

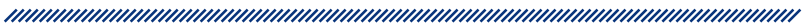

Uvod: promocija zdravlja temeljna je strategija s pomoću koje se mogu kontrolirati faktori rizika za nezdravi način života, a time ujedno poboljšati zdravlje pojedinca i društva. $U$ tom procesu zdravstvene profesije imaju vodeću ulogu.

Cilj: svrha našeg empirijskog istraživanja bila je uvid u ulogu koju zdravstvene profesije imaju u očuvanju zdravlja i dobrobiti elitnih sportaša. Istraživanje se temeljilo na empirijskom fenomenološko-kvalitativnom pristupu, pri čemu smo ispitivali životna iskustva najboljih gimnastičarki i njihovo sudjelovanje u ovom elitnom sportu.

Metode: polustrukturirani intervjui provedeni su na uzorku od 37 gimnastičarki (26 aktivnih, 11 umirovljenih gimnastičarki) i njihova četiri trenera. Transkripcije intervjua analizirane su metodom kvalitativne analize sadržaja.

Rezultati: rezultati su pokazali da sudjelovanje u elitnoj ženskoj gimnastici ima posljedice na fizičko i mentalno zdravlje gimnastičarki te može uzrokovati zlouporabu lijekova protiv bolova, nedostatak obrazovanja, određene žrtve i negativne obrasce ponašanja u odrasloj dobi nakon završetka sportske karijere. Navedene posljedice također su uzrokovane verbalnim i fizičkim nasiljem trenera, interesom društva koje je važnije od interesa sportaša i nedostatkom stručne i osobne podrške za vrijeme treniranja i natjecanja. Takva iskustva gimnastičarki potvrdili su i sami treneri.

Zaključak: istraživanje je omogućilo značajan uvid u mogućnost novih kvalitetnijih pristupa razvoju darovite djece u elitnim sportovima, kako bi se izbjegli mogući faktori rizika i kako bi se osigurala sigurnost, zdravlje i dobrobit svakog djeteta.

Ključne riječi: sestrinstvo, fizioterapija, zdravstveno obrazovanje, promocija zdravlja, vrhunski sport, dobrobit i zdravlje sportaša 